\title{
HUME: A TEORIA SOCIAL COMO SISTEMA
}

\author{
Rolf Kuntz* \\ rolf.kuntz@grupoestado.com.br
}

RESUMO Hume defende na Investigação sobre o Entendimento Humano a parcimônia no uso de princípios explicativos. Tenta-se mostrar, neste artigo, como ele procurou seguir essa diretriz em seus trabalhos sobre os sentimentos morais, a história, a política e a economia. Explora-se, ao mesmo tempo, o caráter sistemático do projeto enunciado no começo do Tratado da Natureza Humana.

Palavras-chave Hume, Empirismo, Iluminismo Escocês, Teoria Monetária, Divisão do Trabalho, Liberalismo, História da Inglaterra, Sentimentos Morais

ABSTRACT In his Enquiry on Human Understanding Hume proposes a rule of parcimony in the use of explanatory principles. This essay is an attempt to show how the philosopher managed to follow that rule in his writings on moral sentiments, history, politics and economics. At the same time, it explores the systematic character of the project described in the presentation of the Treatise on Human Nature.

Keywords Hume, Empiricism, Scottish Enlightenment, Money Theory, Division of Labour, Liberalism, History of England, Moral Sentiments

* Professor da FFLCH-USP. Artigo recebido em 28/11/2011 e aprovado em 26/12/2011.

KRITERION, Belo Horizonte, no 124, Dez./2011, p. 457-490. 
Economista, historiador e teórico político, David Hume mostrou competência e criatividade em várias disciplinas da área social, mas foi um mau juiz da própria obra. Cometeu pelo menos dois erros de avaliação. O primeiro foi quando renegou o Tratado sobre a Natureza Humana, um fracasso editorial. O segundo, quando apontou a Investigação sobre os Princípios da Moral como o "incomparavelmente melhor" de seus livros. Com todos os seus possíveis defeitos, o Tratado, obra de juventude, é há muito tempo considerado seu trabalho mais importante pelos leitores mais cuidadosos. O livro deveria corresponder a um projeto ambicioso. Segundo anunciou numa advertência, o autor pretendia discorrer sobre o entendimento, as paixões, a moral, a política e a crítica. A promessa foi parcialmente cumprida. Nos trabalhos posteriores sobre economia, política, história, crítica e religião, Hume não só reexpôs, mas ampliou, aprofundou e enriqueceu tecnicamente as teses apresentadas no Tratado. Seus ensaios econômicos bastariam para garantir-lhe um lugar importante na história das ciências humanas, por suas contribuições às teorias sobre a moeda, os preços, o comércio internacional e o desenvolvimento. Mas o livro de juventude se manteve como a grande matriz de uma obra ampla, diversa e claramente sistemática. O projeto de um sistema é indicado pelas conexões entre os grandes segmentos dessa primeira obra - Do Entendimento, Das Paixões e Da Moral - e pelo potencial explicativo atribuído a uns poucos princípios.

Imaginem alguém bastante distraído para chegar à seção XII do livro III do Tratado sem perceber as articulações da obra. Será um choque. Qual o vínculo, perguntará o leitor espantado, entre relações sexuais e relações internacionais, excluídos, naturalmente, episódios como o rapto de Helena? A resposta é mais prosaica do que poderia sugerir Teresa Filósofa. Para decifrar a questão basta confrontar a moral do sexo masculino com a dos príncipes. A comparação, desenvolvida por Hume, é uma boa comprovação de sua parcimônia no uso de princípios explicativos. Uma inteira liberdade sexual para os homens é contrária ao interesse da sociedade civil, mas a castidade masculina é socialmente menos importante que a das mulheres. Esta é essencial à estabilidade do vínculo familiar e, portanto, ao cuidado da prole. Logo, a obrigação moral do macho deve ser proporcionalmente menor que a da mulher. Da mesma forma, a fidelidade às promessas e acordos é necessária à paz, ao comércio e ao bom funcionamento do sistema internacional, mas a lei das nações admite uma flexibilidade maior que a lei de natureza.

A mesma obrigação natural, derivada do interesse, vincula tanto reinos independentes quanto indivíduos, "mas, embora o intercurso de diferentes Estados seja vantajoso, e às vezes até necessário, não é tão necessário nem tão 
vantajoso quanto entre indivíduos". Afinal, a natureza humana nem mesmo sobreviveria sem as ligações interpessoais. A obrigação moral entre Estados é mais fraca e "necessariamente devemos, portanto, conceder uma indulgência maior a um príncipe ou ministro que engana outro do que a um cavalheiro que rompe sua palavra de honra". Hume sintetiza a comparação entre machos e príncipes em uma fórmula de proporção: segundo "as noções gerais do mundo", as obrigações dos machos em relação à castidade estão para as obrigações das mulheres aproximadamente como as da lei das nações para aquelas da lei natural.

A lei das nações é discutida na seção XI do livro III do Tratado. A seção XII é dedicada à castidade e à modéstia. Se a sequência das duas seções parece inicialmente estranha, a surpresa logo se dissipa. A discussão da moral sexual obedece aos mesmos padrões seguidos na exposição sobre a justiça e sobre as condições indispensáveis à vida social, à cooperação internacional e até à guerra. "As três regras fundamentais da justiça - a estabilidade da posse, a sua transferência por consentimento e o cumprimento das promessas - constituem deveres dos príncipes tanto quanto dos súditos" e são derivadas igualmente da utilidade ou, simplesmente, do interesse dos homens e da sociedade.

Hume explicita essa regra de parcimônia no fim da seção III da Investigação sobre os Princípios da Moral: "Quando um princípio se demonstrou muito poderoso e eficaz em um caso, está inteiramente de acordo com as regras filosóficas, e mesmo da razão ordinária, atribuir-lhe eficácia comparável em todos os casos similares. Esta, de fato, é a regra principal da atividade filosófica, para Newton". A referência é ao livro III dos Principia. Em alguns momentos ele parece rejeitar o critério da simplicidade. Alguns teóricos da moral foram longe demais "em sua paixão por um princípio geral único", observa Hume na seção inicial da Investigação sobre o Entendimento Humano ${ }^{1}$. Mas a expectativa de encontrar "alguns princípios gerais" para dar conta de todos os vícios e virtudes é desculpável, acrescenta logo depois. Esforços semelhantes deram algum resultado "nos campos das artes, da lógica e mesmo da política". Em outros textos, como no começo do livro II do Tratado, sua adesão à norma da parcimônia, ou simplicidade, é apresentada de forma inequívoca. No "curso da natureza", afirma Hume, efeitos variados comumente decorrem de poucos e simples princípios. Ele chega a atribuir o atraso da filosofia moral à rara observância dessa norma. A fidelidade a essa regra é um dos aspectos mais notáveis da filosofia moral de Hume e o principal fator de unidade de 
seus escritos: um número muito restrito de teses fundamentais aparece nos textos sobre economia, história, política e sociologia (ou psicologia social) e confere a toda a obra um caráter sistemático.

Que um cético tenha produzido um dos mais coesos sistemas do século 18, cobrindo tantas disciplinas, pode parecer estranho, mas não mais estranho que o elogio do pensamento abstruso no começo da Investigação sobre o Entendimento Humano e na abertura do ensaio Sobre o Comércio, uma espécie de introdução geral aos textos econômicos. Aponta-se "a filosofia profunda e abstrata" como "fonte inevitável de erro e de incerteza" e essa é "a objeção mais justa e plausível a uma parte considerável dos estudos metafísicos" ". Mas essa, acrescenta Hume, não é uma razão suficiente para os filósofos desistirem de suas pesquisas. Nem os homens deixarão de ser curiosos, nem os filósofos estarão condenados, necessariamente, a fracassar em todos os seus esforços. Mais uma vez o sucesso da filosofia natural é invocado ${ }^{3}$ como exemplo e fonte de esperança para a atividade especulativa. E mais uma vez, como no Tratado, o exame da natureza humana é apontado como o caminho para a determinação das condições do conhecimento possível.

O ensaio Do Comércio é aberto com uma vigorosa defesa do pensamento filosófico, mesmo quando o afastamento em relação ao senso comum parece imprudente. Hume declara de forma inequívoca sua preferência pelos "pensadores abstrusos". Podem errar o alvo, por excessos, mas oferecem novidades e abrem caminho a descobertas importantes. A "conversa dos cafés", própria dos "pensadores superficiais", jamais produzirá resultados semelhantes. "Raciocínios gerais parecem intricados meramente por serem gerais e não é fácil para a maior parte da humanidade, distinguir, num grande número de particulares, a circunstância comum em que todos coincidem ou extraí-la, pura e sem mescla, de outras circunstâncias supérfluas". Mas, apesar de intricados, princípios gerais, se justos e sólidos, "devem prevalecer sempre no curso geral das coisas, embora possam falhar em casos particulares". É função principal dos filósofos e dos governantes levar em conta esse curso geral. Essa introdução serve como prefácio aos textos econômicos e como advertência ao leitor: ele deve preparar-se para encontrar raciocínios incomuns, talvez muito refinados, na aparência, para "objetos tão vulgares". Talvez sejam falsos, mas ninguém deveria, segundo Hume, rejeitá-los simplesmente por serem incomuns. Essa introdução contém, portanto, uma espécie de manifesto filosófico, uma advertência ao leitor e uma justificativa prática para a investigação científica: 
o conhecimento do "curso geral das coisas" é necessário à administração do Estado. Esse caráter prático da reflexão econômica permeia todos os ensaios. São todos polêmicos e dirigidos não apenas contra um determinado conjunto de teorias, mas também contra certas práticas políticas. Tanto essas teorias quanto essas práticas seriam mais tarde identificadas como mercantilistas. $\mathrm{O}$ rótulo comum pode ser impreciso, mas serve para marcar as principais diferenças do pensamento clássico em relação a ideias dominantes entre escritores e políticos até meados do século 18. Em suas versões mais populares, a história do pensamento econômico vincularia a mudança de paradigma principalmente a Adam Smith e David Ricardo. Mas, quando a Riqueza das Nações foi publicada, em 1776, alguns autores já haviam avançado muito na crítica do mercantilismo e na construção dos fundamentos da economia clássica. Hume, Quesnay e Turgot merecem boa parte do crédito - a maior, provavelmente por esse trabalho.

\section{O sujeito autocentrado}

Os escritos econômicos, assim como os outros Ensaios Morais, Políticos e Literários, são bem mais detalhados e tecnicamente desenvolvidos que as exposições contidas no segundo e no terceiro livros do Tratado. Além disso, são redigidos como textos independentes e autossuficientes. O leitor pode entender suas teses centrais sem recorrer a outras obras de Hume. Pontos importantes das teorias sobre o entendimento, as paixões e a moral são retomados, de forma resumida, quando necessários para esclarecer o ponto de vista humiano. Mas só o Tratado oferece a visão geral do projeto como um sistema.

Um claro exemplo de como as teses fundamentais são retomadas em cada escrito aparece no ensaio Da Origem do Governo. A referência à "grande" e "incurável fraqueza" da natureza humana remete à distinção entre impressões fortes e fracas, ou representações próximas e concepções abstratas. $\mathrm{O}$ homem frequentemente se deixa "desviar de seus interesses grandes e importantes, mas distantes, pelo brilho de tentações muitas vezes próximas, mas presentes", afirma Hume no ensaio. Não podendo mudar a própria natureza, o homem deve buscar algum paliativo - noção também presente no Tratado. O remédio encontrado é o governo, ou, mais especificamente, pessoas encarregadas de "proferir sentenças equânimes, de punir transgressores, de corrigir a fraude e a violência e de obrigar os homens, por mais relutantes que sejam, a levar em conta os próprios interesses reais e permanentes".

Hume retoma em poucas palavras, nesses comentários, noções longamente desenvolvidas no Tratado. Uma delas é a do governo como remédio 
para uma deficiência natural e incurável, a incapacidade de levar em conta, em todos os momentos, as leis da justiça e da equidade e, portanto, os interesses da sociedade. Sendo "mpossível mudar ou corrigir algo importante em nossa natureza, o máximo que podemos fazer é transformar nossa situação e as circunstâncias que nos envolvem, tornando a observância das leis da justiça nosso interesse mais próximo, e sua violação, nosso interesse mais remoto" ". Outra noção fundamental, no mínimo implícita na maior parte dos escritos humianos, é a distinção entre a força das impressões mais próximas e mais concretas e a dos objetos mais distantes e considerados mais abstratamente. A inclinação dominante é agir em vista dos mais próximos.

Mas Hume desenvolve, aqui, algo mais que a descrição de uma tendência psicológica. O interesse mais distante e mais abstrato - a ordem social - é um interesse objetivo, embora esta palavra não seja usada. A função do aparato judicial e repressivo é, portanto, estabelecer um equilíbrio entre dois valores, o do bem imediato, frequentemente ilusório, e o da vantagem permanente propiciada pelo império da justiça. O magistrado e o sistema coercitivo administrado pelo governo têm a função de tornar menos abstrato, ou mais presente, $o$ benefício da ordem legal. Mais precisamente, o papel do poder público, nesse caso, é tornar presente a ideia de um custo bastante grande para contrabalançar o atrativo do comportamento antissocial. Não se trata de reprimir os indivíduos o tempo todo, mas de fazê-los lembrar-se com mais frequência, embora de forma indireta, de seus interesses permanentes e mais importantes.

O mesmo desequilíbrio contábil entre o benefício imediato da violação o vantagem duradoura da ordem legal aparece no capítulo VII do livro I do Contrato Social. "Cada indivíduo, com efeito, pode, como homem, ter uma vontade particular, contrária ou diversa da vontade geral que tem como cidadão [...] Sua existência, absoluta e naturalmente independente, pode levá-lo a considerar o que deve à causa comum como uma contribuição gratuita, cuja perda prejudicará menos aos outros do que será oneroso o cumprimento a si próprio”, escreve Rousseau. Generalizado, esse comportamento levaria à ruína do corpo social: a soma das transgressões, mesmo pequenas, acabaria devastando a ordem coletiva. Daí o compromisso necessário, mesmo quando tácito, para dar força a todos os demais: "aquele que recusar obedecer à vontade geral a tanto será constrangido por todo um corpo, o que não significa senão que o forçarão a ser livre, pois essa é a condição que, entregando cada cidadão à pátria, o garante contra qualquer dependência pessoal". A fórmula espantosa à primeira 
vista, no texto rousseuniano, é a frase "on le forcera d'être libre". Como forçar alguém a ser livre? Mas não há de fato um mistério. Se a prevalência da vontade geral é a condição da liberdade, isto é, da sujeição a si mesmo e não a uma vontade estranha, o homem só pode ser livre pela submissão à lei civil. A repressão o reconduz a seu interesse objetivo e permanente, restabelecendo a correta proporção entre o objeto de atração imediata e o valor duradouro da ordem legal. Violar a norma não é exercer a liberdade, é comprometê-la.

Pode haver enormes diferenças entre as concepções de Hume e as de Rousseau, mas é preciso reconhecer dois pontos de aproximação. Um deles é a distinção entre representações fortes e fracas, com a correspondente diferença entre graus de afetividade e de identificação entre indivíduos. Daí a preferência rousseuniana pelas pequenas sociedades, as mais adequadas, segundo a teoria, ao exercício da liberdade, isto é, da participação do indivíduo nas decisões vitais para a vida coletiva, Daí, também, a desconfiança de Rousseau em relação às almas pretensamente cosmopolitas. O segundo ponto, derivado do primeiro, é a tendência do indivíduo a responder aos estímulos mais próximos e mais concretos, dando prioridade às suas conveniências e às de seus próximos. Quanto maior a sociedade, mais difícil a identificação da vontade comum e maior o peso da ação governamental necessária para manter a ordem e a unidade do Estado. "Quanto menos se relacionem as vontades particulares com a vontade geral, isto é, os costumes com as leis, tanto mais deverá a força repressora aumentar. Conclui-se, pois, que o governo, para ser bom, deve ser relativamente mais forte na medida em que o povo for mais numeroso"s. Em Hume, a limitação das percepções, das paixões e também das virtudes naturais (a benevolência, por exemplo, tem alcance muito restrito) é discutida e exposta num longo trabalho teórico. Não há nada parecido com essa elaboração, em Rousseau. Ele incorpora sem muita discussão certas noções disponíveis num grande fundo comum constituído nos séculos 17 e 18 .

Hobbes foi um dos contribuintes desse fundo, com sua teoria sobre a origem sensível do conhecimento, sua descrição da imaginação e da memória e sua tentativa de estender as noções da mecânica às ciências do homem. Mas vale a pena destacar as contribuições de dois outros autores de reconhecida influência no pensamento iluminista. Pufendorf é uma referência evidente. Ele explora, numa longa passagem do tratado sobre $O$ Direito da Natureza e das Gentes, a oposição entre as perspectivas de curto e de longo prazos, criticando quem se serve da ambigüidade do termo "útil". "Há uma utilidade que só 
aparece como tal ao juízo corrompido das paixões desregradas, as quais, sem se embaraçar com o futuro, se prendem unicamente às vantagens presentes e passageiras. Mas há outra utilidade, fundada nas luzes da reta razão, que não considera só o que tem diante dos olhos, mas examina suas conseqüências" $"$. Jean Barbeyrac, tradutor e comentador de Pufendorf, remete numa nota ao capítulo 21 do Ensaio sobre o Entendimento Humano, de Locke: “Objetos próximos de nossa vista podem ser tomados como maiores do que aqueles de dimensão superior que estão mais distantes. O mesmo ocorre com prazeres e sofrimentos [...] Assim, a maioria dos homens, como os herdeiros perdulários, é capaz de dar mais valor a uma pequena coisa em mãos do que a um grande ganho futuro $[\ldots]^{\prime \prime}$.

Mas a tendência a valorizar mais o benefício próximo - e talvez insignificante ou ilusório - do que o interesse distante, mas duradouro, é apenas parte da história. O indivíduo descrito por David Hume tem outras limitações importantes. Seu mundo afetivo e moral corresponde a uma série de círculos concêntricos. O cosmopolitismo é tão pouco provável nesse universo quanto no rousseauniano. Mais que isso: a benevolência tende a esgotar-se muito antes de atingir os limites de cada sociedade política. A atração entre os sexos, o cuidado da família e a atenção aos próximos esgotam a capacidade natural de se interessar pelos outros. O interesse de cada homem por si e por um círculo restrito de pessoas impediria a vida em grandes sociedades, se nenhum fator interviesse para controlar a inclinação natural dos indivíduos. A parcialidade e a afeição desigual devem não só influenciar o comportamento em sociedade mas também moldar as ideias de vício virtude ${ }^{8}$. Levados apenas por essa inclinação, os homens nunca chegariam a se agrupar em grandes conjuntos. Também não conseguiriam, portanto, reduzir o risco de conflitos em grau suficiente para desfrutar de razoável segurança e ultrapassar as mais primitivas condições de vida.

A coexistência em grupos mais amplos depende de regras mais complexas e de maior alcance que aquelas proporcionadas pela natureza. As virtudes naturais, como a benevolência e a generosidade e a clemência, manifestam-se em atos singulares, completos em si mesmos. Ações guiadas por essas virtudes, ou pelos vícios opostos, "estabelecem relações entre agentes e pacientes

6 PUFENDORF, SAMUEL, Le Droit de la Nature et des Gens, Caen, Bibliothèque de Philosophie Politique et Juridique, 1987, vol. I, p. 183-184.

7 LOCKE, JOHN, An Essay Concerning Human Understandimg, Londres, Penguin Books, p. 251. 8. HUME, DAVID, Tratado da Natureza Humana, p. 529.

8 HUME, DAVID, Tratado da Natureza Humana, p. 529. 
particulares", como bem resume Knud Haakonssen9. O funcionamento de uma sociedade maior, formada por indivíduos e grupos com interesses diversos e muitas vezes conflitantes, depende de vínculos de outro tipo. As condições de coexistência, a começar pelo respeito à integridade de cada um e à propriedade, são necessariamente diferentes daquelas encontradas no meio familiar e nos pequenos grupos.

A solução, inventada, é uma virtude artificial, a justiça. Seu exercício ultrapassa amplamente o alcance das virtudes naturais e a percepção de suas vantagens vai muito além da visão do interesse imediato. Não se trata, é claro, de uma criação instantânea. O entendimento intervém nesse processo, mas o estabelecimento do novo sistema de regras depende um aprendizado resultante da experiência. Até chegar lá, os homens devem ter conhecido as vantagens e prazeres da vida social mais extensa e percebido os obstáculos à sua manutenção. A principal dificuldade é relacionada à estabilidade da posse dos bens exteriores. Trata-se não de renunciar ao interesse próprio em favor do coletivo, mas de criar um sistema de garantias para o desfrute dos bens de cada um. A solução só pode ser um sistema de garantias para todos, baseado em regras estáveis e de aplicação previsível. O primeiro passo é a percepção do interesse comum. Essa percepção se traduz na prática, inicialmente, pela disposição de cada um de se abster dos bens dos demais. Hume usa a palavra convenção, mas não se trata, obviamente, de um acordo instantâneo, e sim de um jogo de expectativas e de um aprendizado. Dessa experiência derivam as ideias de justiça e de injustiça, assim como as de propriedade, direito e obrigação. "Não há dúvida de que a convenção para a distinção das propriedades e para a estabilidade da posse é a circunstância mais necessária para o estabelecimento da sociedade humana, e que, após realizado o acordo para se fixar e observar essa regra, resta pouco ou nada a fazer para o estabelecimento de uma perfeita harmonia ou concórdia." $"$.

O caráter artificial ou abstrato das normas da justiça fica mais claro quando se examinam os diferentes efeitos de sua aplicação. Essas normas são "úteis ao extremo e, na verdade, absolutamente necessárias ao bemestar da humanidade", mas o benefício por elas produzido não resulta de cada ato considerado isoladamente. Sua importância está associada a um "plano ou sistema global" seguido por todos ou pela maioria dos membros de uma sociedade. A aplicação de uma regra de justiça a um caso particular

9 HAAKONSEN, KNUD, Natural Law and Moral Philosophy - FromGrotius to the Scottish Enlnghtenment, Cambridge University Press, 1996, p. 104.

10 HUME, DAVID, Tratado da Natureza Humana, p. 532. 
pode ter consequências perniciosas, como, por exemplo, quando se entrega uma herança a uma pessoa má. $O$ benefício da justiça "provém apenas da observância de uma regra geral" e consiste na manutenção da paz e segurança entre os homens. No terceiro apêndice à Investigação sobre os Princípios da Moral, Hume recorre a imagens da arquitetura para explicar a diferença entre as virtudes naturais, como a benevolência, e a mais importante virtude artificial, a justiça. A felicidade e a prosperidade resultantes das primeiras são comparáveis a um muro construído com muitas pedras empilhadas por muitas mãos, em atos individuais e com objetivos individuais. O efeito social da justiça é semelhante a uma abóbada: cada pedra isolada tenderia a cair e o conjunto só se sustenta pelo arranjo e pelo apoio mútuo de todos os componentes ${ }^{11}$.

Mas serão os argumentos e explicações humianos suficientes para sustentar a qualificacão da justiça como virtude artificial? Sem se render às alegações do próprio Hume, Stephen Buckle o inclui na tradição jusnaturalista e lhe dedica o último capítulo de seu livro Natural Law and the Theory of Property. Buckle aponta, com razão, várias semelhanças entre a construção humiana e a as teorias da lei natural do século 17. Um bom exemplo é a apresentação do sistema da justiça como "adventício e necessário", nascido das circunstâncias e consolidado, ao longo do tempo, como única fundação segura para a vida social. Além disso, chama atenção, com ênfase especial, para o reconhecimento, pelo próprio Hume, de sua dívida em relação a Grotius $^{12}$. Esse reconhecimento aparece no terceiro apêndice à Investigação sobre os Princípios da Moral. "Esta teoria relativa à origem da propriedade, e consequentemente da justiça, é, na maior parte, a mesma sugerida e adotada por Grotius" escreve Hume. Em seguida vem uma citação do livro II, capítulo 2, do Direito da Guerra e da Paz: "Vemos, portanto, que a causa pela qual se renunciou à primitiva comunidade dos bens - em primeiro lugar, à dos bens mobiliários, e, em seguida, à dos bens imobiliários - foi certamente o fato de que os homens, não mais se contentando para seu sustento com aquilo que a terra por si mesma produzia, nem com o fato de morarem em cavernas, de andarem nus ou cobertos apenas de cascas de árvores ou peles de animais, quiseram viver de maneira mais confortável; e para isso foi preciso que um dedicasse sua perícia a uma coisa, outro a outra $[\ldots]$ " etc.

Essa teoria nem é inteiramente atribuível a Grotius, nem passou diretamente dele a Hume sem ser absorvida por outros autores no intervalo.

11 HUME DAVID, Uma Investigação sobre os Princípios da Moral, Campinas, Editora da Unicamp, 1995, p. 199.

12 BUCKLE, STEPHEN, Natural Law and the Theory of Property - Grotius to Hume, Oxford, Clarendon Press, 1991, p. 296-297. 
A referência à comunidade original de bens e ao seu abandono a partir de certas mudanças na forma de vida dos homens é encontrada em Sêneca, na carta 90 da série daquelas destinadas a Lucílio. Locke retoma o essencial dessa tese tanto no Primeiro quanto no Segundo Tratado sobre o Governo. Em Locke, como em Grotius, a propriedade é apresentada como um direito natural, mas a noção de um direito natural adventício aparece mais claramente na obra grociana. $\mathrm{O}$ foco de Hume não é inicialmente a ideia de direito, mas o problema da estabilidade da posse dos bens exteriores. Esse problema é desconhecido nas sociedades mais limitadas e mais simples, "quando os bens e os prazeres da vida são poucos e de pouco valor". "Um índio não se sente muito tentado a se apossar da cabana de outro ou a roubar seu arco, porque já possui esses mesmos benefícios; quanto a qualquer riqueza superior que possa advir a um deles na caça ou na pesca, será apenas casual e temporária, e não terá uma tendência muito grande a perturbar a sociedade"13. Grupos nesse estágio de desenvolvimento podem viver sem governo e só ocasionalmente, na guerra, submetem-se a um chefe.

Regras de propriedade só aparecem quando a posse de bens externos se torna insegura. Mesmo essa mudança deve ter ocorrido de forma gradual, com os homens aprendendo lentamente, pela experiência, a vantagem de se abster cada indivíduo dos bens alheios. Mas em algum momento é preciso fixar regras para distinguir os bens de cada um e para determinar os modos de aquisição e de transferência. Estabelecida a convenção sobre a abstinência da posse dos outros, surgem as ideias de justiça e injustiça, "bem como as de propriedade, direito e obrigação". "Estas últimas", acrescenta Hume, "são absolutamente ininteligíveis sem a compreensão das primeiras"14. A ênfase no problema da segurança e não no tema do direito marca bem a diferença entre Hume e os jusnaturalistas do século anterior. Ele não se mostra interessado, como Locke, por exemplo, em estabelecer os fundamentos morais ou ontológicos da propriedade. Ele até pode mencionar a ação do homem sobre a natureza, mas não se detém no exame de como o esforço do sujeito estabelece uma relação moral entre com a coisa. "O trabalho de seu corpo e a obra de suas mãos, pode-se dizer, são propriamente dele. Qualquer coisa que ele então retire do estado com que a natureza a proveu e deixou, mistura-a ele com o seu trabalho e junta-lhe algo que é seu, transformando-a em sua propriedade", escreve Locke $^{15}$.

13 HUME, DAVID, Tratado da Natureza Humana, p. 578-579.

14 Idem, p. 531.

15 LOCKE, JOHN, Dois Tratados sobre o Governo, S. Paulo, Editora Martins Fontes, 1998, p. 409. 
Para Hume não tem sentido, como já foi indicado, falar de propriedade antes de fixadas entre os homens as normas da justiça. $\mathrm{O}$ direito de propriedade não é apenas adventício, como são, para Locke, as normas civis concebidas para a garantia de um direito anterior à sociedade política e a qualquer convenção. Não é essa a perspectiva humiana. Para ele, a relação moral e a natural não se dão ao mesmo tempo, nesse caso, “A propriedade de uma pessoa é algum objeto a ela relacionado; essa relação não é natural, mas moral, e fundada na justiça. É absurdo, portanto, imaginar que possamos ter uma ideia de propriedade sem compreender completamente a natureza da justiça e mostrar sua origem no artifício e na invenção humana. A origem da justiça explica a da propriedade"16. Hume, no entanto, mais de uma vez se refere às invenções como leis naturais e junta as duas noções em frases enigmáticas à primeira vista. Ele menciona, por exemplo, a "invenção" de leis da natureza relativas à estabilidade da posse e à sua transferência. Páginas adiante, há uma referência às "três leis fundamentais" da natureza, "a da estabilidade da posse, a de sua transferência por consentimento e a do cumprimento das promessas" ${ }^{17}$.Três artifícios, mas, ao mesmo tempo, três leis fundamentais da natureza? A união dessas palavras pode parecer ainda mais intrigante quando se encontra, a partir do parágrafo seguinte, um longo arrazoado contra a noção da justiça como virtude natural. Mas convém retomar a leitura lentamente. Logo depois de mencionar as três leis "naturais", Hume acrescenta: "A paz e a segurança da sociedade humana dependem inteiramente da estrita observância dessas três leis; não há nenhuma possibilidade de se estabelecerem boas relações entre os homens quando elas são desprezadas. A sociedade é absolutamente necessária ao bem-estar dos homens; e essas leis são igualmente necessárias à sustentação da sociedade".

A referência às três leis como indispensáveis à sustentação da sociedade remete às distinções estabelecidas no final da exposição inicial sobre a justiça. Nessa passagem, Hume esclarece o leitor sobre o uso da palavra natural. Numa acepção, a palavra é tomada simplesmente como oposta a artificial. É essa a mensagem, quando ele nega à justiça o qualificativo de natural. Mas o termo tem outros significados. "Quando uma invenção é evidente e absolutamente necessária, é tão correto considerá-la natural quanto tudo que proceda imediatamente de princípios originais, sem a intervenção do pensamento ou reflexão". Isso se aplica às normas da justiça e Hume ainda acrescenta: "Tampouco é impróprio utilizar a expressão Leis Naturais para caracterizá-las, se entendermos por natural aquilo que é comum a uma espécie qualquer, ou 
mesmo se restringirmos seu sentido apenas ao que é separável dessa espécie”. Essas qualificações se aplicam perfeitamente à condição dos homens em sociedade. O esforço de esclarecimento é retomado na Investigação sobre os Princípios da Moral. A “naturalidade” da justiça, nesta explicação, é vinculada à necessidade humana de viver em sociedade e à indispensável criação de regras para a preservação da propriedade e das condições de coexistência. "Em um animal tão sagaz, aquilo que surge necessariamente do exercício de suas faculdades intelectuais pode com justiça ser considerado natural". Outros esclarecimentos são acrescentados numa nota, mas, no final, Hume parece perder a paciência: "Todas estas disputas, porém, são meramente verbais". Nem tanto, ou ele não gastaria tanto esforço para explicar por que considera artificiais a propriedade e a justiça. Além disso, o foco no direito como solução de um problema - o da insegurança da posse - e não como atributo independente da ordem política marca uma enorme diferença entre o pensamento humiano e a tradição da lei natural do século 17. Hume incorpora em seus textos várias noções postas em circulação por outros autores e disponíveis no grande fundo da tradição filosófica. Essas ideias trazem as marcas evidentes de grandes figuras como Grotius, Hobbes, Locke e Pufendorf. Também a herança de autores mais próximos, como Hutcheson e Mandeville, é identificável sem muita dificuldade. Em alguns casos, a apropriação da ideia ocorre sem grandes mudanças. Em outros, a herança é amplamente reprocessada e ganha um significado novo. É o caso do legado jusnaturalista. Apropriadas por David Hume, tornam o seu discurso parecido com o dos teóricos da lei natural e do direito natural, mas apenas parecido, porque o jusnaturalismo foi posto de lado.

\section{A perspectiva econômica}

A economia tem uma importância especial na teoria social de Hume. No centro dessa teoria está um sujeito egoísta, preocupado principalmente consigo, com sua família e com seus próximos, embora seja capaz de participar de associações maiores e de criar esquemas complexos de cooperação. Apesar de autocentrado, esse indivíduo não pode viver isoladamente. Animais de outras espécies são naturalmente equipados para se alimentar, para se adaptar ao meio e para se defender. $\mathrm{O}$ animal humano é o menos preparado para isso. Até este ponto da descrição estamos num território familiar, já percorrido, por exemplo, na Lição sobre o Poder Civil de Francisco de Vitória ${ }^{18}$, nas primeiras 
páginas do Direito da Guerra e da Paz, de Grotius, e no livro II dos Deveres do Homem e do Cidadão, de Pufendorf ${ }^{19}$. Não haveria novidade nessa passagem, se Hume se limitasse a lembrar as deficiências do homem, quando comparado com outros animais, e a afirmar, com base nisso, uma sociabilidade imposta pela necessidade. Ele impõe sua marca à teoria da sociabilidade ao descrever as vantagens da vida social. Ao se associar, o homem supera três problemas: a limitação de suas forças, a necessidade de atender sozinho a múltiplas carências e o risco "da ruína e da miséria" no caso de um infortúnio. A marca humiana fica mais clara quando os argumentos são expostos de outra perspectiva: "A conjunção de forças amplia nosso poder; a divisão do trabalho [partition of employments] aumenta nossa capacidade; e o auxílio mútuo nos deixa menos expostos à sorte e aos acidentes" ${ }^{20}$. O segundo ponto faz toda a diferença para caracterizar a perspectiva de Hume. Ao incluí-lo entre as vantagens da vida em sociedade ele introduz de imediato um elemento fundamental de sua teoria do desenvolvimento econômico. Quase quatro décadas mais tarde, esse elemento é destacado na primeira frase do primeiro capítulo da Riqueza das Nações: "O maior aprimoramento das forças produtivas do trabalho e a maior parte da habilidade, destreza e bom senso [judgement] com os quais é em toda parte dirigido ou executado parecem ter resultado da divisão do trabalho". Hume retoma esse tema em vários momentos, tanto nos escritos mais técnicos sobre economia quanto nos textos históricos.

Elemento fundamental das teorias do desenvolvimento e também das teorias modernas do comércio internacional, a divisão do trabalho é o primeiro componente marcadamente econômico da teoria social humiana. O segundo é a noção de escassez. Os homens só precisaram inventar a propriedade e a justiça porque os bens exteriores são escassos e expostos à rapina. A sociedade permite o aperfeiçoamento (e a maior oferta) daqueles bens. A sua escassez, no entanto, motiva o conflito e impediria a vida social, se a imaginação combinada com a experiência não produzisse um arranjo para regular a posse e as formas de transferência dos bens.

Os elementos básicos de uma teoria do desenvolvimento são apresentados no ensaio Do Comércio, texto de abertura dos escritos econômicos compilados nos Ensaios Morais, Políticos e Literários. Mas a discussão das condições do crescimento, do aperfeiçoamento do sistema produtivo e das relações entre economia, política e cultura se estende por quase toda a obra. 
A maior parte de cada Estado, escreve Hume no ensaio Do Comércio, divide-se entre agricultores e manufatores. Os primeiros cultivam a terra, os segundos transformam as matérias-primas fornecidas pelo primeiros (ou obtidas por meio da extração, poderia ter acrescentado o autor, mas podese deixar de lado este detalhe). "Quando deixam o estado de selvageria, em que se sustentam principalmente pela caça e pela pesca, os homens sempre se encaixam nessas duas classes, embora as artes da agricultura inicialmente empreguem a parte mais numerosa da sociedade" 21 . Diferentemente de outros autores do século 18, incluído Adam Smith, Hume não se empenha em detalhar as grandes etapas do desenvolvimento, desde as atividades mais elementares da coleta, caça e pesca até a fase comercial, passando pelo pastoreio e pela agricultura. Ele avança diretamente da etapa mais primitiva para um cenário de divisão do trabalho. A agricultura predomina durante algum tempo, admite Hume, mas o seu interesse está em outro ponto: o mecanismo da transformação, centrado nos ganhos de produtividade. "Os aprimoramentos que o tempo e a experiência trazem a essas artes são tão grandes que a terra pode facilmente sustentar um número muito maior de homens do que o que são empregados diretamente em seu cultivo ou que fornecem as manufaturas que lhes são mais necessárias" 22 . Esse ganho de eficiência permite a liberação de mais braços para outras atividades e, portanto, para uma diversificação maior da produção. É fácil imaginar, a partir desse ponto, uma dinâmica de crescimento alimentada pela multiplicação das demandas, pelo aperfeiçoamento das técnicas e pela estimulação recíproca dos vários setores. Mas, antes de dar esse passo, Hume interrompe a exposição para responder a uma pergunta política: não poderia o soberano reclamar para si essas mãos supérfluas, empregando-as na atividade militar para aumentar seu poder e expandir seus domínios? A pergunta é formulada porque o ensaio é voltado inicialmente para o exame da relação entre o comércio e a grandeza do Estado. A palavra "comércio", neste caso, é usada para designar uma economia caracterizada pela diversificação das atividades e pelas trocas entre as pessoas ocupadas nos diferentes setores.

Como faz com frequência, Hume recorre à história para discutir o problema. A antiguidade oferece exemplos de Estados poderosos militarmente e com a economia pouco diversificada. Esparta é uma referência óbvia. "Os hilotas eram trabalhadores; os espartanos, soldados ou cavalheiros. É evidente que o trabalho dos hilotas não seria suficiente para manter um grande número de espartanos se estes vivessem em meio a conforto e a delicadezas e empregassem um grande 
número de mercadores e manufatores". Condições semelhantes foram observadas em outros Estados antigos. Poderia um soberano moderno retomar essa política? "A isso respondo", escreve Hume, que tal coisa parece praticamente impossível, dado que a política dos antigos era violenta e contrária ao curso mais natural usual das coisas." A argumentação inclui uma lista de peculiaridades culturais e econômicas dos Estados antigos, como a pequena dimensão dos Estados livres da Antiguidade, a frequência das guerras, e o espírito público estimulado pela constante ameaça externa e em fatores de ordem análoga.

Para explicar o "curso normal das coisas", ele aponta certas características típicas do homem, como o desejo de bem-estar, a avareza e a ambição de ganho. Essas paixões podem não se manifestar simultaneamente, até porque o espírito de poupança tende a limitar o impulso do consumo. Esse espírito de poupança, de fato, nem mesmo se manifesta senão em condições particulares, depois que o desenvolvimento de uma atividade lucrativa chega a fazer do ganho um objetivo maior. "Suscitar a frugalidade e e elevar o amor pelo lucro acima do prazer é uma consequência infalível de todas as profissões industriosas", escreve Hume no ensaio dedicado aos juros ${ }^{23}$. Mas essas formas de comportamento - a frugalidade e a poupança - só se manifestam quando a vida social, a divisão das atividades , o aperfeiçoamento das artes e a expansão do comércio atingiram um considerável grau de desenvolvimento. É esse o percurso normal da história, quando circunstâncias especiais não sufocam certas inclinações dos homens.

As transformações geradas pelo amor do bem-estar, do ganho e, depois, pelo espírito de poupança, seguem um processo de realimentação e de autoreforço. A diversificação das atividades e a expansão do comércio conferem preeminência e poder aos mercadores. Estes "geram indústria, pois servem como um canal que a espalha por todos os cantos do Estado; ao mesmo tempo, sua frugalidade permite que adquiram grande poder sobre a indústria e reúnam uma grande propriedade do trabalho e das mercadorias, de que são os principais instrumentos na produção". Da atividade intensa e da frugalidade resulta um crescente estoque de capital disponível para empréstimo a juros baixos e isso realimenta a expansão dos negócios. No longo prazo - pois é esta a perspectiva humiana - a redução dos juros decorre não da expansão da oferta de moeda, mas do aumento da poupança e, portanto, do capital utilizável para financiamento. $\mathrm{O}$ aumento da moeda em circulação só estimula a atividade econômica por um breve período, pois seu principal efeito - e 
o único, em prazo maior - é o aumento de preços. Sem o comércio, afirma Hume, o Estado é constituído principalmente pela nobreza perdulária e por camponeses sem recursos para alimentar um grande fluxo de empréstimos a custo reduzido ${ }^{24}$. Juros baixos, segundo Hume, são um sinal de economia próspera e de abundância de produtos e de recursos.

Nas condições normais do mundo moderno, a tentativa de reprimir as artes e o comércio resultaria mais provavelmente em perda para o soberano e, portanto, em enfraquecimento do Estado. A limitação das manufaturas e das artes mecânicas (e, portanto, do comércio) afetaria o conjunto da sociedade e também os agricultores seriam desestimulados pela redução de oportunidades de negócios. Os braços tornados supérfluos pelos ganhos anteriores de eficiência ficariam sem ocupação. Não haveria estímulo a novos aperfeiçoamentos do trabalho e da indústria, porque não haveria como trocar os produtos adicionais. Em outras palavras, o próprio avanço da agricultura, condição essencial ao avanço da urbanização, tenderia a desaparecer, sem o estímulo gerado pela expansão de um mercado fora do campo. Disso resultaria não só a estagnação da agricultura, mas também, pela indolência, a perda de qualidade dos homens nela empregados. O Estado se enfraqueceria, por falta de homens capazes de servir à causa pública em caso de necessidade. Então, quanto mais trabalho seja empregado para suprir mais que as necessidades básicas, mais poderoso será o Estado, porque as pessoas dedicadas a esse tipo de atividade serão fácil e vantajosamente recrutadas para o serviço público. "Um Estado sem manufatores pode igualmente dispor da mesma quantidade de pessoas, mas a quantidade de trabalho não é a mesma, nem do mesmo tipo, pois ali todo trabalho é empregado em necessidades às quais não é possível renunciar" 25 .

A defesa do comércio como fator de fortalecimento do Estado inclui o elogio do refinamento das artes. "O aumento e o consumo de todas as mercadorias que servem para o ornamento e o prazer da vida são vantajosos para a sociedade, pois, ao mesmo tempo em que multiplicam as inocentes gratificações dos indivíduos, são uma espécie de estoque de trabalho que, diante de exigências do Estado, pode ser voltada para o serviço público"26. Numa nação sem esses prazeres, continua Hume, os homens mergulham na indolência e o Estado não consegue manter adequadamente suas forças armadas. "As fronteiras de todos os reinos europeus são, no presente, quase 
as mesmas de duzentos anos atrás; mas qual a diferença de poder e grandeza desses reinos?" A resposta, segundo Hume, está no aumento da arte e da indústria de alguns desses Estados.

A divisão do trabalho tende a ocorrer também entre as nações e o comércio exterior, quando se desenvolve sem as distorções provocadas pela interferência governamental, promove a prosperidade de todos os participantes e o fortalecimento dos Estados envolvidos. Mas o poder do Estado, neste caso, será usado mais proveitosamente para a interação econômica com os parceiros do que para a guerra e a conquista. Políticas orientadas pelo temor da competição e da importação dos produtos estangeiros são para Hume um erro grave e prejudicial à sociedade e ao poder soberano. Quando se consideram as vantagens da diversificação de atividades e da expansão das trocas, a condição dos Estados, argumenta Hume, é semelhante à das pessoas: "Um indivíduo dificilmente será industrioso se os seus vizinhos são ociosos. As riquezas de muitos membros da comunidade contribuem para aumentar as minhas, qualquer que seja minha profissão, pois consomem o produto de minha indústria e fornecem-me o produto da sua em retorno"27.

Hume economista comanda boa parte do trabalho de Hume historiador. O exame atento dos arranjos econômicos, das transformações dos sistemas de produção e de comércio, da tributação e do gasto público é uma das marcas da História da Inglaterra. Tome-se a análise, por exemplo, do reino de Elisabeth, no terceiro apêndice do volume IV. "Para entender a antiga constituição da Inglaterra, nenhum período merece mais estudo que o reino de Elisabeth", escreve Hume ao introduzir a discussão. $\mathrm{O}$ cenário é paradoxal à primeira vista. As prerrogativas da rainha foram raramente contestadas, ela as empregou amplamente e "sem escrúpulo", recorreu à violência e, no entanto, desfrutou de grande popularidade. O mistério é apenas aparente. Aquela popularidade foi possível, segundo Hume, porque Elisabeth nunca infringiu as "liberdades estabelecidas do povo"28. Ou, como sugerido no parágrafo inicial do apêndice: nem violou essas liberdades nem julgou necessário conceder aos súditos mais liberdade do que aquela desfrutada por seus ancestrais.

Hume discute nesse texto o estilo de governo de Elisabeth, o funcionamento dos tribunais, o sistema penal, as finanças da Coroa, o comércio, a extensão dos poderes da rainha, além, naturalmente, dos costumes da nobreza e do renascimento cultural. Diante desse amplo e animado painel, o leitor talvez nem perceba um detalhe nada irrelevante: comentários sobre economia e 
finanças compõem quase quarenta por cento do texto. Hume não se limita, por exemplo, a comparar o governo inglês do período elisabetano com o governo turco ainda no século 18: "O soberano tem todos os poderes, exceto o de impor tributos ao povo. Nos dois países, essa limitação, sem a compensação de outros privilégios, parece sobretudo prejudicial ao povo." No caso da Turquia, porque o sultão permite as extorsões praticadas pelos paxás e pelos governadores de províncias, para depois tomar-lhes presentes ou imporlhes confiscos. Na Inglaterra, porque essa restrição levou a rainha a criar monopólios e a conceder patentes para comércio exclusivo. Se isso tivesse sido levado mais longe, comenta Hume, a Inglaterra, "sede de riquezas, artes e comércio, teria no presente tão pouca indústria quanto o Marrocos ou a costa da Barbaria".

Hume descreve outras formas de extorsão fiscal, como empréstimos compulsórios sem juros, imposição de embargos comerciais condicionados a benefícios para a Coroa e vários expedientes de tributação disfarçada. Mas a rainha era frugal e, além disso, dispunha de rendimentos proporcionados por direitos alfandegários e por seus bens. Boa parte da despesa pública era destinada a custear "o esplendor da corte", mas Elisabeth conseguiu, em geral, suportar esses gastos. Mais que isso: liquidou, segundo se dizia, dívidas de 4 milhões de libras deixadas por seu pai e por seus irmãos - uma espécie de herança maldita.

Ao examinar o comércio, Hume retoma a crítica dos monopólios e privilégios, esboçada na passagem sobre a limitação do poder de tributar. Ele aponta como um dos erros de Elisabeth a decisão de criar monopólios para estimular o comércio e a navegação e estabelecer, dessa forma, o poder naval necessário à segurança do reino. Essa iniciativa tenderia a produzir exatamente o oposto do efeito desejado, desencorajando a atividade interna, já que apenas alguns privilegiados controlariam o intercâmbio externo. No entanto, prevaleceu "o espírito da época", fortemente inclinado para os empreendimentos navais, as descobertas e a exploração de oportunidades em mercados distantes. Aqui, o historiador faz contraponto ao economista teórico dos ensaios sobre o comércio internacional e crítico das práticas mercantilistas.

A atenção à economia se estende à descrição dos costumes e às mudanças de hábitos da nobreza. Pouco a pouco aristocracia substitui os gastos com a hospitalidade e o sustento de agregados pelas despesas com roupas, novas edificações e objetos de luxo, disso resultando novos estímulos à indústria e às artes, em vez do "vício, da desordem, da sedição e da ociosidade" associados às velhas formas de vida. A referência ao consumo de bens de luxo e ao refinamento do gosto e das artes logo remete ao desenvolvimento da 
manufatura e do comércio. A mesma relação aparece em vários dos ensaios políticos e econômicos. Mas a mudança dos hábitos de consumo, além de estimular a atividade produtiva, acaba afetando a relação entre de poder entre os grupos sociais. Enquanto predominavam os velhos costumes, os barões dissipavam fortunas com o luxo da hospitalidade e mantinham uma "ascendência ilimitada" sobre as pessoas mantidas por sua mesa ou dedicadas ao seu serviço. Com os novos padrões de consumo, passaram a relacionarse com artesãos e comerciantes sustentados com independência pelo próprio trabalho.

Nessa nova relação, o poder dos aristocratas foi reduzido à "moderada influência" dos clientes sobre seus fornecedores ${ }^{29}$. Uma relação desse tipo, segundo Hume, "nunca pode ser perigosa para o governo civill". A conversão do senhor em consumidor mudou a distribuição de poder entre os súditos e a relação entre a nobreza e a Coroa. Da mesma forma, os proprietários de terras, precisando mais de dinheiro que de homens, alteraram a forma de exploração de suas propriedades, tornando a agricultura mais lucrativa e liberando trabalhadores para a cidade. $\mathrm{O}$ enfraquecimento da aristocracia, nesse período, não resultou apenas de uma ação do poder central ou de uma aliança da monarquia com a burguesia ascendente. A própria ascensão da classe burguesa só é inteligível a partir de uma análise da transformação dos costumes, dos padrões de consumo e das condições de produção, e a análise humiana valoriza precisamente esses dados.

\section{Economia, poder e moral}

O exame dos dados econômicos mostra-se igualmente fecundo quando se trata de examinar processos muito mais longos de transformação política e social. Hume interrompe o fio da narrativa, no final do capítulo 23 do segundo volume da História da Inglaterra, para um balanço antecipado das grandes transformações ocorridas entre o século 11 e o começo da modernidade ou a "aurora da civilidade e das ciências", no século 15. Depois de resumir muito rapidamente o período de retração cultural e econômica iniciado com a decadência do império romano, ele chega a um ponto de inflexão, no século 11. Há sempre, segundo Hume, um limite para os períodos de exaltação ou de depressão, e a partir desse ponto a tendência se inverte. A mudança, nesse caso, é de um ambiente de violência e insegurança para um cenário de maior 
estabilidade e melhores condições para o desenvolvimento das luzes. Parte da melhora decorreu do aumento da segurança externa, associado a um fator econômico: tendo aprendido as artes da agricultura, os dinamarqueses e outros povos do norte conseguiram "certa subsistência" em casa e puderam dispensar a "precária sobrevivência por meio da rapina e da pilhagem de seus vizinhos". Mesmo os governos feudais, no sul, foram reduzidos a "uma espécie de sistema" e ofereceram alguma tranquilidade depois de um longo período de desordem.

Novas mudanças nos costumes e nas formas de produção e de organização da vida material seriam necessárias, antes de se chegar àquela "aurora da civilidade e das ciências". Hume destaca duas grandes transformações na ordem econômica. Uma foi o desenvolvimento das atividades manufatureiras e mercantis nas cidades, primeiro na Itália, depois na França e em seguida em outros países, até atingir a Inglaterra. As corporações envolvidas nessas atividades foram protegidas privilégios e governos separados e assim puderam escapar da tirania dos barões. A outra grande alteração ocorreu no interior dos domínios feudais. Gradualmente, os senhores dispensaram os servos da terra da prestação de serviços pessoais, permitindo-lhes dedicar-se exclusivamente à agricultura. Aqueles serviços, embora muito custosos para os servos, eram de pouca importância para os barões e valiam menos, afinal, que o produto da atividade rural. Gradualmente os senhores descobriram também ser mais vantajoso deixar aos agricultores a responsabilidade pela destinação de seu produto. Com isso se alterou a relação entre o dono da terra e o seu usuário, com o pagamento da renda (isto é, do aluguel do solo) substituindo a prestação de serviços. Deixando de lado a linguagem do próprio Hume, pode-se resumir essa história como sendo a passagem da produção feudal para a agricultura capitalista, baseada em ganhos de produtividade e livre acesso ao mercado. Nessa evolução, a propriedade perde o caráter de elemento de dominação pessoal e transforma-se em fonte de renda (aluguel). "O interesse do senhor e o do servo (slave é a palavra usada) concorreram para a mudança" e com isso a servidão (villenage) "entrou gradualmente em desuso nas partes mais civilizadas da Europa" 30 .

A crescente segurança da propriedade foi um fator importante para o aumento da produção e, portanto, para todas as mudanças decorrentes dos ganhos de produtividade e discutidas mais extensamente no ensaio Do Comercio. As terras eram mais bem cultivadas onde o produtor desfrutava 
de segurança de sua posse, escreve Hume na História da Inglaterra, e com isso começou a prevalecer o sistema de concessão de uso (lease) e os vínculos de servidão se romperam totalmente. Esse vínculo entre direitos - de fato ou respaldados por lei - e as práticas econômicas é recorrente nos escritos históricos e teóricos de Hume. Neste caso, a mudança legal completa ocorreu muito depois da consolidação das alterações no sistema produtivo e da extinção da diferença entre servo e homem livre. Mas o sistema jurídico havia começado a transformar-se muito antes do esboroamento do regime feudal, a partir da importação de novas concepções desenvolvidas no continente.

Nesse capítulo da História Hume presta uma rara homenagem ao clero católico, pela preservação da cultura na Idade Média e pela renovação do pensamento jurídico a partir da redescoberta do direito romano. "Talvez nenhum evento", escreve ele, "tenha contribuído tanto para o aperfeiçoamento daquela era quanto [...] o encontro de uma cópia dos Pandectas de Justiniano por volta do ano 1.130 na cidade de Amalfi, na Itália" ${ }^{31}$. O clero estudou e difundiu esse "excelente sistema" de concepções jurídicas por toda a Europa e em menos de dez anos o assunto era discutido em Oxford. Os eclesiásticos tinham interesse nessa difusão, em parte porque a sede do antigo império romano era também a sede de sua igreja e em parte porque desejavam maior segurança para suas posses em toda a Europa. Mas essa ressalva tem muito menos, no comentário humiano, do que o reconhecimento dos méritos do novo sistema e dos efeitos positivos de sua adoção em muitos Estados europeus.

O sistema romano jamais foi adotado internamente na Inglaterra, mas foi em grande parte "transferido secretamente para a prática das cortes de justiça". Além disso, os ingleses, desejando imitar os vizinhos, "esforçaramse para gradualmente elevar a própria lei de sua condição original de rudeza e imperfeição" "32. De certa forma, a adoção dos padrões do direito romano, mesmo sem a sua incorporação no sistema legal, teve um efeito civilizatório em toda a Europa e, de modo especial, "entre os saxões ou ingleses antigos", por causa da "extrema imperfeição" de sua jurisprudência. Na Inglaterra ainda prevaleciam práticas como a autorização de vinganças privadas, da compensação em dinheiro por qualquer crime e do duelo. "Esse estado da sociedade era muito pouco avançado em relação ao rude estado de natureza", comenta Hume, numa rara referência - metafórica, naturalmente - à condição natural descrita pelos contratualistas. A metáfora, neste caso, refere-se à passagem de uma situação sem lei e sem segurança para um mundo ordenado 
segundo regras fixas e objetivas de justiça. É a mesma transição descrita no livro III do Tratado e mencionada no ensaio Da Origem do Governo, uma evolução necessária tanto ao desenvolvimento das artes quanto à dinamização e à diversificação da atividade produtiva.

É o caso, talvez, de se perguntar se há, no pensamento de Hume, uma precedência dos fatores econômicos ou dos arranjos sociais e institucionais na ordem causal. Em alguns momentos ele acentua a influência das mudanças econômicas nos demais aspectos da vida coletiva, ao apontar, por exemplo, a passagem da agricultura servil para a comercial como um fator de redistribuição de poder. Em outras passagens, a consolidação das instituições de justiça aparece como liberadora das forças produtivas e da capacidade criadora nas artes e nas técnicas. A mesma aparente ambiguidade ocorre na discussão dos vínculos entre as artes e a liberdade. "Uma vantagem fundamental derivada da introdução e do progresso das artes foi a introdução e progresso da liberdade e esta consequência afetou os homens tanto na sua capacidade pessoal quanto na civil", está escrito na História ${ }^{33}$. No entanto, o ensaio Da Ascensão e Progresso das Artes e Ciências contém uma tese à primeira vista contrastante: "Minha primeira observação sobre esse assunto é que é impossível que as artes e ciências ascendam primeiro em meio a um povo qualquer se esse povo não desfruta da bênção de um governo livre" 34 .

A tese do ensaio é sustentada com uma extensa argumentação histórica e política, A cultura não pode florescer em sociedades bárbaras, onde os homens buscam antes de mais nada proteção contra a violência e a injustiça mútua e se tornam dependentes de chefes capazes de se impor pela força. $\mathrm{O}$ ambiente será ainda menos propício ao desenvolvimento cultural se o poder for concentrado nas mãos de um homem, "Esperar, portanto, que as artes e ciências surjam primeiro numa monarquia é esperar uma contradição. Antes que esses refinamentos tenham lugar, o monarca é ignorante e desinstruído e, sem conhecimento suficiente para torná-lo sensível à necessidade de balancear seu governo em leis gerais, ele delega plenos poderes a todos os magistrados inferiores. Essa política bárbara degrada o povo e impede para sempre todo aprimoramento" "35. Este comentário abre caminho para uma comparação entre o regime republicano e o monárquico e sobre as possibilidades da cultura e da liberdade em cada um. Não é o caso, neste momento, de avançar longamente nesta discussão. Deve ser suficiente a indicação de 
alguns pontos, a começar por um dado favorável à república, isto é, ao regime caracterizado por eleições e pela participação do povo: mesmo uma república bárbara "dá à luz o direito, "antes mesmo que "os homens tenham realizado avanços consideráveis em outras ciências" 36 . "Do direito surge a segurança; da segurança, a curiosidade, e da curiosidade, o conhecimento." Mas o surgimento da luzes pode dar-se também pelo contágio resultante da vizinhança de números Estados independentes e ligados pelo comércio e pela política - um fator mencionado mais de uma vez nos ensaios políticos e econômicos. A fragmentação dos Estados e a consequente limitação do poder igualmente facilitam o aparecimento das condições necessárias ao progresso do conhecimento e das artes. Além disso, os sistemas políticos podem mudar, por influência de vários fatores, e assim o comércio e as artes podem florescer também nas monarquias absolutas, observa Hume no ensaio Da Liberdade Civil. "Como discuto aqui as alterações que o tempo produziu ou poderá produzir na política, devo observar que todos os gêneros de governo, livres e absolutos, parecem ter experimentado, em tempos modernos, uma mudança para melhor no que se refere à administração externa e doméstica". Com isso se pode dar conta do notável florescimento das letras, das artes e das ciências, assim como do comércio, na França absolutista. A segurança da propriedade parece ter-se tornado tão segura "numa monarquia europeia civilizada quanto numa república" e, além disso, é preciso considerar a força da avareza, móvel da indústria, diante de obstáculos de todo tipo. Se o comércio tende a decair em governos absolutos, continua Hume, não é por ser menos seguro, mas menos honroso. Como a subordinação de classes é necessária à manutenção da monarquia, "nascimento, títulos e cargos devem ser honrados acima de indústria e riquezas" 37 .

Retomando a questão: haverá precedência de alguma classe de fatores na ordem da causalidade? O exame da História, dos Ensaios e do Tratado sugere uma resposta mais complexa do que a indicada na formulação da pergunta. Há um jogo de influência recíproca entre os vários fatores e, embora Hume não recorrra a essa imagem, suas descrições apontam um processo de realimentação. Ora a alteração econômica afeta a distribuição de poder e a vida política, ora a mudança no exercício de poder libera o potencial produtivo e a criação nas artes e nas ciências e assim por diante. Os textos citados até agora mostram a causalidade operando em mais de um sentido. Mas é preciso, também, levar em conta a importância atribuída por Hume aos impulsos elementares não 
só da sobrevivência, mas também da ação produtiva e da criação de formas crescentemente complexas de organização econômica. As três vantagens básicas da vida social, tais como descritas no Tratado, são a agregação de forças, a divisão do trabalho (a possibilidade de aperfeiçoamento em cada atividade) e a segurança diante do infortúnio. O problema da segurança da propriedade e, portanto, da justiça, só se manifesta com a multiplicação das ocasiões de conflito e impõe a busca de um arranjo artificial e mais complexo que a mera associação. Esse arranjo é a vida política.

Alguns ordenamentos políticos são mais favoráveis que outros ao desenvolvimento do comércio, das artes, das ciências e - como síntese de todas as condições mais favoráveis à manifestação das capacidades humanas - da liberdade. A comparação entre regimes frequentemente assume a forma do confronto entre monarquia e república. Mas o contraste essencial, no pensamento humiano, não é de fato entre os sistemas monárquico e republicano, mas entre governos despóticos e governos livres, ou, mais precisamente, entre regimes com diferentes graus de autoridade ou de liberdade e com diferentes níveis de segurança para a propriedade. Em algumas passagens a ênfase da linguagem humiana dificulta a percepção de certas distinções mais finas. A discussão sobre formas de organização política e liberdade fica mais clara quando se examinam mais de perto alguns detalhes da análise política. Até aqui, houve referências principalmente às funções básicas do governo proporcionar segurança externa e interna e garantir a aplicação de normas de justiça. Mas o conjunto é bem mais complexo e um de seus aspectos mais interessantes é uma teoria sobre a autoridade.

Como podem os governantes mandar no povo, conseguir submissão e conseguir dos indivíduos a renúncia a seus interesses e paixões? Não pode ser só pela força, porque, nesse caso, a vantagem estaria do lado dos governados. "Portanto", afirma Hume, "o governo funda-se tão somente na opinião, e essa máxima vale tanto para os governos mais despóticos e militarizados quanto para os mais livres e populares" ${ }^{38}$. As opiniões podem ser de interesse e de direito. A primeira se vincula "principalmente" à percepção das vantagens derivadas do governo e de sua estabilidade. A segunda pode referir-se a dois tipos de direito - ao poder e à propriedade. $\mathrm{O}$ interesse próprio, o medo e a afeição podem também afetar o exercício da autoridade, mas, segundo Hume, não exercem influência independentemente das opiniões a respeito do interesse público, do direito ao poder e do direito à propriedade. A combinação 
desses princípios favorece diferentes formas de organização institucional e de exercício do poder, não só pela aceitação da autoridade, mas também pela maior ou menor lealdade a cada tipo de governo. Neste ensaio (Dos Primeiros Princípios de Governo) o objetivo de Hume é obviamente a elaboração de uma teoria sobre os fundamentos da obediência ou, se se quiser usar um conceito mais moderno, da legitimidade no sentido da sociologia política weberiana.

Ele não chega a estabelecer uma tipologia como a de Weber, mas evoca diferentes configurações do poder com diferentes limites da autoridade. No ensaio seguinte, Da Origem do Governo, Hume acrescenta uma qualificação essencial à sua análise da extensão e dos limites do poder político. Cabe, aqui, uma citação longa: "Em todos os governos", escreve, "há uma luta perpétua e entranhada, aberta ou secreta, entre AUTORIDADE e LIBERDADE, mas nenhuma delas pode prevalecer na disputa. [...] O sultão é senhor da vida e da fortuna de cada indivíduo, mas não pode impor novos impostos a seus súditos. Um monarca francês pode impor impostos a seu bel-prazer, mas percebe o perigo de atentar contra a vida e a fortuna de indivíduos. Também a religião é, na maioria dos países, um princípio intocável, e outros princípios ou preconceitos frequentemente resistem a toda autoridade do magistrado civil, cujo poder se funda na opinião [...]"39. Se esta descrição traduzir, de fato, o ponto de vista de Hume, a hipótese do governo perfeitamente despótico só terá sentido como um caso limite concebido por abstração. Se as configurações do poder fossem descritas por uma curva determinada por duas séries de valores - autoridade e liberdade - dispostos em dois eixos, as combinações de fato sempre estariam entre os extremos. A sociedade é sempre mais que um ajuntamento de objetos inertes ou passivos diante do poder. Para admitir essa hipótese seria preciso descartar a natureza humana tal como concebida na teoria humiana. $\mathrm{O}$ artifício da política é necessário porque os homens não podem mudar essa natureza, mas apenas criar condições de controle de algumas de suas manifestações. $\mathrm{O}$ poder político tem essa função - mas também é incapaz de mudar ou de anular essa natureza.

Hume expõe a sua concepção do homem a partir de uma descrição de como o indivíduo recebe e processa os estímulos sensoriais e de como as paixões afetam o seu comportamento. Os atributos do indivíduo são essenciais para a construção da teoria social humiana, mas esse "individualismo" é muito mais complexo que o de Hobbes e a concepção política dele resultante é muito diferente. Apesar de seu interesse predominante por si e pelos próximos, esse 
sujeito é, por assim dizer, condenado à vida social. "Em todas as criaturas não predadoras e que não são agitadas por paixões violentas manifestase um notável desejo de companhia, que faz com que se associem umas às outras, sem que possam pretender tirar qualquer proveito dessa união. Isso é ainda mais visível no homem, que é, dentre todas as criaturas do universo, a que tem o desejo mais ardente de sociedade e está preparada para ela pelo maior número de circunstâncias favoráveis. "Uma única paixão, a simpatia, anima todas as demais - orgulho, ambição, avareza, curiosidade, vingança ou luxúria. Nenhuma delas teria força, "se fizéssemos abstração dos pensamentos e sentimentos alheios" $" 40$.

O conceito de simpatia é fundamental, no pensamento humiano, tanto para a construção de uma teoria da interação social quanto para a elaboração da teoria política. Adam Smith pode ter ido mais longe na exploração desse conceito, em sua Teoria dos Sentimentos Morais, mas a contribuição de Hume tem sido provavelmente subestimada, embora o tema seja discutido tanto no exame das paixões, no segundo livro do Tratado, quanto na exposição sobre a moral, no terceiro livro. No livro II, o assunto aparece numa seção sobre a estima dedicada aos poderosos e ricos. Aqui, Hume antecipa alguns tópicos e argumentos da exposição smithiana. Um exemplo é a referência ao prazer causado pela contemplação de objetos e instalações de conforto mesmo quando o observador não desfruta pessoalmente desses benefícios. Tudo se passa como se o espectador se pusesse no lugar do proprietário. "Entramos em seu interesse pela força da imaginação, e sentimos a mesma satisfação que esses objetos naturalmente nele ocasionam" ${ }^{41}$. Cinco parágrafos adiante: "Podemos observar, em geral, que as mentes dos homens são como espelhos umas das outras, não apenas porque cada uma reflete as emoções das demais, mas também porque as paixões, sentimentos e opiniões podem reverberar várias vezes, deteriorando-se gradual e insensivelmente". A metáfora do espelho, retomada por Smith, é especialmente útil, na Teoria dos Sentimentos Morais, para a descrição de como os valores e a moralidade se formam no espaço intersubjetivo. Desse jogo resultam não só padrões pessoais de julgamento, mas um padrão socialmente dominante, expresso nas avaliações do espectador imparcial.

No livro III, essas teses são parcialmente reexpostas na seção dedicada às virtudes e aos vícios naturais. "As mentes de todos os homens são similares em seus sentimentos e operações; ninguém pode ser movido por um afeto que 
não possa ocorrer também nas outras pessoas, seja em que grau for. Como cordas afinadas no mesmo tom, em que o movimento de uma se comunica à outra, todos os afetos passam prontamente de uma pessoa a outra, produzindo movimentos correspondentes em todas as criaturas humanas [...] Nenhuma paixão alheia se revela imediatamente à nossa mente. Somos sensíveis somente às suas causas ou efeitos. É desses que inferimos a paixão; consequentemente, são eles que geram nossa simpatia." ${ }^{42}$. O texto reproduz em seguida, com outras palavras, as considerações sobre os efeitos da observação das coisas belas e úteis. O ponto mais importante para a teoria política vem adiante: "Esse mesmo princípio produz, em muitos casos, nossos sentimentos morais, assim como os do belo. Nenhuma virtude é mais apreciada que a justiça, e nenhum vício mais detestado que a injustiça $[. . .]^{\prime 43}$.

Hume desenvolve a exposição, a partir desse ponto, discorrendo sobre como os homens aprovam, por simpatia, virtudes artificiais valorizadas por serem benéficas à sociedade e à humanidade, como a justiça, a obediência civil, a modéstia e o respeito ao direito internacional. Este é um ponto crucial para a construção da teoria política. É fácil explicar racionalmente por que os homens precisam da autoridade e esse ponto é exposto no Tratado e com clareza ainda maior no ensaio Da Origem do Governo. A imposição da lei pela força do poder comum compensa, de certa forma, o caráter abstrato do interesse geral. No entanto, a referência ao poder da autoridade conta apenas uma parte da história. Apesar da força dos interesses mais próximos, o indivíduo é capaz de valorizar o coletivo. A injustiça nos desagrada mesmo quando é distante e não afeta diretamente nosso interesse, "pois a consideramos prejudicial à sociedade humana" e "participamos, com simpatia", do desprazer imposto à vítima do ato injusto. "Assim, o interesse próprio é o motivo original para o estabelecimento da justiça, mas uma simpatia com o interesse público é a fonte da aprovação moral que acompanha essa virtude"44. A observação é acompanhada de uma ressalva: "Este último princípio, da simpatia, é fraco demais para controlar nossas paixões; mas tem força suficiente para influenciar nosso gosto e para nos dar os sentimentos de aprovação ou de condenação". A vida política é muito mais que um arranjo de poder para regular a coexistência de indivíduos egoístas.

O egoísmo é um dado e o conflito, também, mas o estado pré-político, tal como descrito por Hume, não é uma condição de indivíduos atomizados. 
O surgimento do poder político marca uma etapa da experiência coletiva e responde a uma necessidade gerada por mudanças nas condições materiais de vida. Isso já foi indicado neste comentário. A invenção da justiça responde a uma crise de crescimento: sem um mecanismo para disciplinar a posse dos bens exteriores e as formas de apropriação e transferência, a sociedade entraria em colapso. Nessa altura, o grupo social envolve, com certeza, relações muito mais complexas que do que seriam os vínculos criados por uma cooperação eventual e passageira. A função primária do poder político é fortalecer esses vínculos e impedir seu rompimento. A nova forma de articulação dos indivíduos não surge de um ato criador. O progresso natural dos sentimentos é insuficiente para garantir a manutenção da vida social, mas é "favorecido pelo artifício dos políticos, que, com o intuito de governar mais facilmente os homens e preservar a paz na sociedade humana, buscaram produzir um apreço pela justiça e uma aversão pela injustiça". Mas os políticos podem apenas, com seu esforço, estender os sentimentos "além de seus limites originais". Não podem criá-los. Precisam dispor da matéria-prima, isto é, de alguma noção das distinções morais fornecida pela natureza ${ }^{45}$. Essas noções são reforçadas pelo elogio público e pela condenação dos comportamentos, assim como pela educação e pela instrução privada e pelo valor atribuído, afinal, à reputação. Desde cedo transmitidos às crianças, "os sentimentos de honra podem criar raízes em suas mentes delicadas, adquirindo tal firmeza e solidez que não ficam muito aquém dos princípios mais essenciais à nossa natureza e mais profundamente enraizados em nossa constituição interna"46.

Inútil, portanto, procurar em Hume uma teoria política pura, de tipo mecanicista, construída sem referência a formas de interação moral independentes da ação de um poder comum. A política humiana é construída sobre a base de uma psicologia social e também isso o distancia do universo hobbesiano. Embora valorizando o modelo da física clássica e aproveitando elementos da política de Grotius, Hobbes, Locke e Pufendorf, Hume e Smith abrem caminho para uma teoria social muito diferente da seiscentista.

\section{Ceticismo e liberalismo}

Não se pretende neste artigo discutir ponto a ponto a construção do sistema humiano e testar no detalhe a coerência de seus textos. Esse exercício é em muitos casos improdutivo. Como em Rousseau, a consistência é dada, 
neste caso, muito mais pelas grandes linhas do pensamento - pela unidade substancial, como diria Goldschmidt - do que pela ênfase ocasional num ou noutro ponto ${ }^{47}$. Parece difícil, depois de todos os pontos expostos e discutidos até aqui, por em dúvida não só a intenção sistemática de Hume, mas também seu sucesso na construção de um amplo conjunto de análises psicológicas, políticas, econômicas e histórias a partir de um conjunto restrito de princípios e de teses.

Que um pensador rotulado como cético tenha empreendido um trabalho desse tipo já não deve surpreender ninguém há muito tempo. Primeiro, porque o ceticismo de Hume, seja qual for a sua qualificação, não se sobrepõe às exigências da natureza. Os homens não deixarão de agir e de viver para seguir qualquer raciocínio abstrato. Evitarão jogar-se no abismo, terão cuidado com o fogo e escolherão seus alimentos entre aqueles considerados mais seguros, embora sejam incapazes, pelo exercício da filosofia, de afirmar com certeza demonstrativa uma relação causal ou qualquer proposição relativa a questão de fato. Não há demonstração no raciocínio moral, referente a questões de fato e de existência: "não é contraditório que o curso da natureza possa mudar e que um objeto aparentemente semelhante aos de que tivemos experiência possa vir acompanhado de efeitos diferentes ou contrários. Tentar demonstrar por argumentos prováveis a conformidade do futuro com o passado seria "andar em círculo e tomar como dado" exatamente o ponto em debate. De fato esperamos efeitos semelhantes de causas semelhantes, mas essa expectativa não é produzida pela razão nem pode resultar de qualquer número de experiências. No entanto, só um "insensato ou louco" poderia "por em questão a autoridade da experiência ou rejeitar essa grande condutora da vida humana"48.

Mas o ceticismo não é superado ou atenuado apenas pela força de uma natureza defensora de seus direitos. De modo geral, os homens se orientam pela experiência comum ou por ideias mais ou menos elaboradas e complexas. Assim sobrevivem tanto os sábios quanto os indivíduos de cultura limitada. Mas a contenção do ceticismo vai além da prática cotidiana e este é o segundo ponto. As pessoas com propensão para a filosofia continuarão a filosofar, pelo prazer dessa ocupação e também porque "as decisões da vida comum nada mais são do que os pensamentos da vida comum metodizados e corrigidos". A filosofia pode ser uma exigência da natureza para algumas pessoas. "Sinto

47 GOLDSCHMIDT, VICTOR, Anthropologie et Politique - Les Príncipes du Système de Rousseau, Paris, Librairie Philosophique J. Vrin, 1974, p. 12.

48 HUME, DAVID, Investigações sobre o Entendimento Humano e sobre os Princípios da Moral, p. 66. 
crescer em mim a ambição de contribuir para a instrução da humanidade e de conquistar um nome por minhas invenções e descobertas. Tais sentimentos brotam naturalmente em minha disposição presente; e, se eu tentasse erradicálos, dedicando-me a qualquer outra tarefa ou divertimento, sinto que perderia no âmbito do prazer; e esta é a origem de minha filosofia"49.

Ninguém é obrigado a filosofar, mas quem sente essa inclinação pode, apesar de todas as limitações do entendimento, entregar-se à reflexão com a esperança de produzir algo de valor. "Enquanto uma imaginação ardorosa for admissível em filosofia, e enquanto se aceitar que hipóteses possam ser abraçadas meramente por especiosas ou agradáveis, jamais poderemos ter princípios firmes ou sentimentos adequados à prática e à experiência comuns. Mas, se algum dia essas hipóteses forem eliminadas, poderemos ter então esperanças de estabelecer um sistema ou conjunto de opiniões que, se não verdadeiras (pois isso talvez seria esperar demais), sejam ao menos satisfatórias para a mente humana e resistam à prova do exame mais crítico" ${ }^{50}$. Que mais seria necessário para justificar um empreendimento tão ambicioso quanto aquele enunciado no começo do Tratado? Mas a decisão de filosofar pode também garantir um resultado prático de imenso valor. Acolher a filosofia é aceitar raciocínios elaborados e refinados. Para rejeitá-la, devemos basear-nos em raciocínios igualmente complexos, como aqueles desenvolvidos no exame das operações e dos limites do entendimento. Qualquer decisão é difícil, mas uma delas - a recusa do filosofar - tem um custo especialmente alto. É quase impossível, segundo Hume, a mente humana permanecer dentro do "círculo estreito" dos objetos da conversação e da vida cotidiana. É preciso, portanto, escolher o guia mais seguro e agradável. "Quanto a isso, ouso recomendar a filosofia, e não hesito em escolhê-la em lugar da superstição, de qualquer gênero ou nome." A superstição domina facilmente as mentes e frequentenente perturba as ações. Já a filosofia, "se legítima (just), só pode nos oferecer sentimentos brandos e moderados; e, se falsa e extravagante, suas opiniões são objetos de especulação fria e geral e raramente chegam a interromper o curso de nossas propensões naturais".

Há um sentido prático - e especialmente político - na escolha da filosofia. A superstição não perturba somente a vida individual. Afeta a vida coletiva e favorece a tirania, fortalecendo o poder sacerdotal e dificultando a liberdade civil, porque "torna o homem dócil e abjeto e ajusta-o para a escravidão" 
entusiasmo religioso também envolve perigo, por induzir à rebelião, à violência e à instabilidade política, mas "sua fúria é como a do trovão e da tempestade, que logo passam e deixam o ar mais calmo e sereno do que antes". Como é associado à autoconfiança e ao ânimo vigoroso, é favorável à liberdade e à tolerância, Hume relaciona a superstição aos católicos tradicionais e aos tories. O entusiasmo, aos quacres, aos independentes, aos presbiterianos e aos whigs. Ele aponta divisões políticas e religiosas semelhantes em outros países da Europa. No caso da França, a oposição mais notável é entre molinistas, conduzidos pelos jesuítas, e jansenistas. "Os jesuitas são os tiranos do povo; e os jansenistas mantêm acesa a pequena centelha de amor pela liberdade que se encontra na nação francesa" ${ }^{52}$.

Embora manifeste menor rejeição aos entusiastas, Hume tenta manterse distante das duas posições. Ele rejeita a tirania e qualquer pretensão ao poder absoluto. Ao mesmo tempo, defende a monarquia inglesa de seu tempo, moderada pelo poder do Parlamento, por uma legalidade bem estabelecida e, de modo especial, por instituições e costumes favoráveis à liberdade - ou às liberdades, como a de imprensa, por ele descrita como mais ampla do que em qualquer outro governo republicano ou monárquico. A explicação dessa peculiaridade inglesa, segundo Hume, está na organização política: “A razão por que as leis nos permitem essa liberdade parece advir de nossa forma mista de governo, que não é nem inteiramente monárquica, nem republicana". Também aqui aparece a tese a respeito da combinação entre as formas de exercício do poder. Os dois extremos, a liberdade e a escravidão, muitas vezes se aproximam. "Tão logo se abandonem esses extremos, misturando à liberdade um pouco de monarquia, o governo torna-se sempre mais livre; e, por outro lado, quando se mistura à monarquia um quinhão de liberdade, o jugo torna-se sempre mais penoso e intolerável" 53 . Neste ensaio, como em muitos outros, a tese é discutida e sustentada com base em exemplos históricos contemporâneos e do passado. $\mathrm{Na}$ Inglaterra prevalece a parte republicana, embora "com grande mistura de monarquia". Aí, o equilíbrio do regime depende de uma severa limitação dos poderes dos magistrados, por meio de leis "gerais e inflexíveis" concebidas para "assegurar a vida e a fortuna" de cada súdito. A liberdade para vigiar e criticar o governo é um dos instrumentos de segurança: “o poder arbitrário se instauraria entre nós, se não tivéssemos o cuidado de impedir seu progresso; e não há método mais simples para isso do que soar o alarme de uma ponta a outra do reino". A liberdade de imprensa pode dar origem a abusos, mas é 
difícil propor um remédio adequado a esse mal. Hume claramente prefere os inconvenientes dessa liberdade ilimitada aos males derivados da restrição.

Como economista, como escritor político e como cidadão, Hume defende as instituições inglesas de seu tempo e defende maior abertura para a atividade produtiva, para o comércio e, portanto, para o desenvolvimento das artes e das ciências e, portanto, para todos os benefícios consequentes. Há em seus escritos e em suas atitudes políticas uma mistura de conservadorismo e de reformismo. É preciso evitar o radicalismo político e preservar as liberdades e as formas de coexistência estabelecidas e consolidadas a partir da revolução de 1688. Mas é preciso, também, avançar na liberação da atividade produtiva e comercial. A crítica à política dos monopólios, dos privilégios e das barreiras impostas ao comércio é uma tentativa de eliminar resíduos do absolutismo. Os fisiocratas desenvolvem na França uma campanha semelhante. Turgot, amigo e correspondente de Hume, batalha pela liberação do espaço econômico francês e pela difusão de novas práticas de produção e de circulação de mercadorias. O trabalho continuará com Adam Smith, Jean-Baptiste Say e David Ricardo.

Hume descreve a história europeia, desde o ponto de inflexão no século 11, como a construção progressiva de uma sociedade livre. As mudanças econômicas, culturais e políticas vividas entre a fase final do feudalismo e o começo da modernidade produzem em toda parte resultados semelhantes: "Assim, a liberdade pessoal tornou-se quase generalizada na Europa e essa vantagem pavimentou o caminho para o aumento da liberdade política ou civil" 54 . Mesmo quando esse efeito foi incompleto, acrescenta o historiador, a transformação proporcionou aos membros da comunidade alguns dos principais benefícios. A experiência inglesa, segundo ele, tem uma característica especial, porque a vontade do monarca, desde a invasão da ilha pelo saxões, jamais foi "inteiramente absoluta e incontrolada". "Em outros aspectos, no entanto, o equilíbrio de poder mudou amplamente entre as várias ordens do Estado [...]". Hume nunca se mostra bastante otimista para apostar na continuidade indefinida do progresso ou mesmo na preservação das liberdades e das luzes. Sua tese sobre a inflexão histórica depois dos períodos de exaltação ou de depressão nunca é abandonada. Além disso, ele nunca deixa de alertar para os perigos do radicalismo e do partidarismo. Mas a maior parte de seus escritos parece conter pelo menos a crença na possibilidade de um longo período de liberdade e de progresso, se houver suficiente investimento na polidez e no bom senso. 


\section{Referências bibliográficas}

BUCKLE, Stephen, Natural Law and the Theory of Property-Grotius to Hume, Oxford, Clarendon Press, 1995.

GOLDSCHMIDT, Victor, Anthropologie et Politique - les Principes du Système de Rousseau, Paris, Librairie Philosophique J. Vrin, 1974.

HAAKONSEN, Knud, Natural Law and Moral Philosophy -From Grotius to the Scottish Enlightenment, Cambridge University Press, 1996.

HUME, David, Uma Investigação sobre os Princípios da Moral, Campinas, Unicamp, 1995.

HUME, David, Tratado da Natureza Humana, S. Paulo, Editora Unesp, 2000.

HUME, David, Investigações sobre o Entendimento Humano e sobre os Princípios da Moral, S. Paulo, Editora Unesp, 2003.

HUME, David, Ensaios Políticos, S. Paulo, Editora Martins Fontes, 2003.

HUME, David, The History of England, Indianapolis, Liberty Fund.

LOCKE, John, Dois Tratados sobre on Governo, S. Paulo, Editora Martins Fontes, 1998.

LOCKE, John, An Essay Concerning Human Understanding, Londres, Penguin Books.

PUFENDORF, Samuel, Le Droit de la Nature et des Gens, Caen, Bibliothèque de Philosophie Politique et Juridique, 1987.

PUFENDORF, Samuel, On the Duties of Man and Citizen, Cambridge University Press, 1998.

ROUSSEAU, Jean-Jacques, Do Contrato Social, S. Paulo, Nova Cultural, 2005. VITORIA, Francisco de, Obras, edição bilingue latim-espanhol, Madri, Biblioteca de Autores Cristianos, 1960. 